\title{
The Effect of Organizational Culture on Working Disciplines of Madrasah Ibtidaiyah Head Master in Deli Serdang
}

\author{
Muhammad Rifa'i \\ State Islamic University \\ North Sumatera \\ mhd_rifai70@yahoo.com
}

Syafaruddin Siahaan

State Islamic University

North Sumatera

syafaruddinsiahaan@uinsu.ac.id

\author{
Siman Nurhadi \\ State University of Medan \\ Medan \\ simannurhadi@gmail.com
}

\begin{abstract}
The quality of leadership of Madrasah principles are greatly determine the quality of learning in Madrasah.The purpose of this study is to answer the problems surrounding the influence of the organizational culture on the discipline of the head of Madrasah Ibtidaiyah in Deli Serdang. This study is a quantitative research with expost facto design. The research is a survey method and to analyze one variable with other variables and in here used path analysis. The instrument of this research is a questionnaire with a Likert scale. Analysis of this path requires the existence of significant linear regression relationship between variables. Based on path analysis, path coefficient between $x$ and $y$, it is obtained $p_{61}=0.249$ and $t_{0}=$ 2.738. For $\mathrm{N}=113$. At a significance level of $5 \%$, it is obtained $t_{\text {table }}=1.658$. The calculation results produce $t_{0}>t_{\text {table }}(2.738>$ 1.658). Thus $H_{0}$ is rejected and $H_{a}$ accepted, so it can be concluded that organizational culture directly affect the dicipline of work.
\end{abstract}

Keywords: Organizational Culture, Work Discipline

\section{INTRODUCTION}

The Law of National Education System Number 20 Year 2003 states that National Education aims to develop the potential of learners to become human beings who believe and have piety to God Almighty, have a noble character, healthy, knowledgeable, capable, creative, independent, and become democratic citizens and responsible for the intellectual life of the nation[1]. According to Trilling and Hood (1990: 15) education is also a conscious effort because of the deliberate elements of the educator to develop the personality and potential of the children. Education lasts a lifetime in various settings such as family, school and community. As the times progressed, the twentieth century turned into a century of knowledge as mentioned by most people. Futurists refer to it as a century of knowledge because knowledge will be the main foundation of many aspects of life[2]. Education has such a vast role that is played in the arena and the formation of the nation's culture. The impact on education includes curriculum, education management, education personnel, education strategies and methods. Furthermore, Trilling argues that there are eight major trends in Asia that influence the world: (1) from country to network, (2) from export demands to consumer demands, (3) from Western influence to Asian way, (4) from government control to the demands of the market, (5) from village to metropolitan, (6) from labor-intensive to technology, (7) from male dominance to female emergence, (8) from West to East. Rahman said these eight trends will affect the patterns of education. In this connection, education is challenged to be able to prepare human resources capable of facing the challenge of that trend without losing the values of the nation's personality and culture. The success of an organization (madrasah) is the success of a leader or principal. Rahman (2006:106) reveals that the head of a madrasah is a teacher (functional officer) who is appointed to occupy a structural position (head of madrasah) in school[3]. Wahjosumidjo (2002:83) added that the head of a madrasah is a functional teacher who is given the task of leading a school to run the teaching-learning processes, or a place where there is an interaction between the teachers giving the lessons and students receiving the lessons[4] 


\section{THEORETICAL FRAMEWORK}

The principlas of the madrasah is said to be successful in his leadership if they understand the existence of the madrasah as a complex and unique organization, and capable of performing their roles as principals. One of the roles in question is to influence and mobilize others to work towards the vision and the mission of the school without any coercion. Hadari and Nawawi (2006:36) stated that the success of leadership is determined by the ability to control a number of people into a solid team by Martin and Nawawi[5]. The same is also stated by Soebagia(2000:161) that the leadership of education requires a major concern because through good leadership, qualified personnel in various fields as thinkers or workers who ultimately can improve the quality of human resources will be born[6]. In this regard, the quality of leadership of the madrasah principlas will greatly determine the quality of the learning in madrasah. If the leadership quality of the madrasah principal is good, the implementation of the learning goes well and teachers work optimally. Based on the grand tour conducted in Deli Serdang District, there are some things that require serious attention within the issues of the improvement of work discipline of madrasahs principlas, such as absenteeism, uniform use that is not in accordance with the rules, the inaccuracy of hours of entry and return of work, office neglect during working hours. The result of interview with the head of Madrasah Education Ministry of Religious Affairs of Deli Serdang Regency on March 28, 2016 shows that the percentage of employee absenteeism is still high. It is also explained that there arel many headmasters who do not meet the provisions of working hours, such as the office hours which are not in accordance with the schedule or even worse, leaving the madrasah during working hours. The results of the interviews with some head of Madrasahs, especially of private Madrasah Ibtidaiyahs who allegedly behave undisciplinedly, it is known that they show such behavior because of lack of satisfaction in their works. This is due to the increasing difficulty of meeting the family's life needs from the salary received. Other factors are due to the feeling of unfair treatment, lack of attention from leadershis, low guarantee of opportunity for promotion, and lack of positive recognition of work performance. Besides, there is a negative perception due to the in the amount of salary reveived, the opportunity to get a periodic salary increase between employees who show good performance and less good performance. If this is not handled correctly, the headmasters who show good levels of disciplines might be affected by less disciplined principals. In an organization, discipline is a very important factor needed to realize the goals of the organization because without good disciplines, an organization can not achieve high effectiveness and efficiency. Discipline is a positive behavior that essentially visible in the form of attitude, behavior and deeds in accordance with applicable regulations, both written and unwritten.

Hasibuan(2005:194) explained that the discipline of work is the awareness and willingness of a person to comply with the corporate rules and social norms that apply[7]. The same is also expressed by Gouzali(2006:111) who said that the discipline of work is interpreted as attitudes and behaviors of an employee embodied in the form of an employee's willingness with full awareness, sincerity without coercion in complying with and implementing all the rules and policies of the company in carrying out the duties and responsibilities as efforts to give maximum contribution in achieving the institution goals [8].

Carrell, Elbert, and Hatfield (1995:702) mentioned that discipline is the part that animates the overall management function in improving the performance of each individual and organization. This means that all activities undertaken without discipline will not produce a useful performance[9]. Different views, however, expressed by Dessler (2009:194) who argues that discipline is interpreted as an exercise or education of propriety and spirituality and the development of the nature to encourage employees to behave carefully by obeying the rules and decisions[10]. This exercise or education is one of the foundations for members of an organization or group to be able to realize all its goals. This is because discipline refers to order by Jhon W. Newstrom (2007:236)[11].

While Darmodihardjo in Sinaga (2010:34) argues that the discipline of work is a mental attitude that contains the willingness of the heart that can be seen from the behavior to meet all the rules, regulations and norms that apply in fulfilling the duties and responsibilities within an organization[12]. Discipline, according to Suseno (2009:110), is a management activity to run the standards of the organization[13]. This means that the objectives determined and agreed upon by the members of the organization will be consciously achieved if they respect and enforce rules and regulations applicable within the organization. Colquit, Lepine, and Wesson(2009:8) in the form of a model called Integrative Model of Organization Behavior affirms that individual outcomes considered to influence performance behavior and organizational commitment consist of: job satisfaction, stress, motivation, trust, justice and ethics, and learning and retrieval decision[14]. Meanwhile, individual mechanisms are influenced by organizational mechanisms comprising organizational culture and organizational structure, group mechanisms, consisting of leadership styles and behaviors, leadership powers and influences, team processes, team characteristics, and individual characteristics, consisting of: personality and cultural values and abilities.

Based on this model, it is shown that performance behavior and organizational commitment is reflected in compliance and submission with respect to applicable provisions. This behavior is commonly known as work disciplines. Susilo mentioned that the factors affecting employee disciplines include motivation, education and trainings, leadership, welfares and discipline enforcement. Pratiwiningsi states that the factors of salary, leadership, motivation, and communication also affect employee's work disciplines. While Erawati in Bangsawan added that organizational culture, leadership, and compensation also influence employee's work disciplines. Based on the opinion of these experts above at least set the limitation that 
indeed many factors are considered to influence the disciplines of work, including commitment factors, organizational culture, motivation and organizational satisfaction consisting of: job satisfaction, stress, motivation, trust, equity and ethics, decision-making. Meanwhile, individual mechanisms are influenced by organizational mechanisms comprising, organizational culture and organizational structure, group mechanisms, consisting of leadership style and behavior, leadership power and influence, team processes, team characteristics, and individual characteristics, consisting of: personality And cultural values and abilities. Based on this model, organizational performance and commitment behaviors are reflected in obedience, submission and compliance respecting the prevailing provisions commonly known as work discipline. Susilo(2007:165) mentioned that the factors that affect employee discipline include motivation, education and training, leadership, welfare and discipline enforcement[15]. Pratiwiningsi (2006:2) states the factors of salary, leadership, motivation, and communication affect employee work discipline[16]. The opinions of the experts above at least provide restrictions that there are many factors that are considered to influence the disciplines of work, including factors of commitment, organizational culture, motivation and satisfaction.

Organizational culture is also a determinant factor of a job satisfaction and work disciplines. Culture is defined as the order of knowledge, experience, belief, values, attitudes, meanings, hierarchy, religion, time, roles, relationships, space, the concept of the universe, material objects and possessions acquired by a large group of people from generation to generation through both individual an group's efforts. Culture tells employees about how things are done and what matters, in addition to what can or should not be done which can be said as a guideline used to run the activities of the organization. Lunenburg and Ornstein (2004:89-90) assert that organizational culture affects employee performance, organizational effectiveness, organizational structural processes and many other management or administrative processes such as motivation, leadership, decision making, communication, and changes[17].

Organizational culture also has a direct effect on work discipline. This is similar to the opinion of Moekijat (2002:356) who states that the discipline of work done by an employee arises because of the command discipline[18]. Command discipline is the discipline that is commanded. That is, the discipline that comes from a recognized power and uses the "scary" means of obtaining the exercise through the rules or culture within the organization.Thus, the discipline of employees is influenced by the culture within the organization. Frinaldi's (2010:6) research results show a positive relationship between organizational culture and work disciplines. Based on the theory and some of the above research results, duty commitment directly affects job satisfaction and work disciplines[19].

Kreitner and Kinicki (2004:112) define organizational culture as the glue of the organization that binds members of the organization through its adhered values, symbolic tools, and social goals to be achieved. A well-developed organizational culture can drive people within an organization to perform work activities. Unconsciously, everyone within an organization learns the culture that prevails in its organization. It is further said that the system of shared meanings, when examined more closely, is a set of key characteristics appreciated by the organization. Recent research relates to the characteristics suggests that there are seven essential characteristics of an organization's culture, namely: (1) Innovation and Risk Taking referring to the extent to which employees are encouraged to be innovative in taking risks. (2) Attention to detail refers to the extent to which employees are expected to show precision (accuracy), analysis, and attention to details, (3) Outcome orientation refers to the extent to which management focuses on results, not on techniques and processes used to achieving that results, (4) People's orientation refers to the extent to which management decisions affect people within the organization. (5) Team orientation refers to the extent to which work activities are organized around teams, not individuals. (6) Aggressiveness refers to the extent to which people are aggressive and competitive rather than casual, (7) Stability refers to the extent to which organizational activities emphasize the status quo rather than growth[20].

Each of these characteristics takes place on a continuum from low to high. A composite image of an organization will be obtained using these seven characteristics. This description will then become the basis for a shared understanding of the organization, of how the affairs are resolved in it and how members are expected to behave. These characteristics can be mixed to create a very diverse organization. In line with this, Hofstede (1986:20) also argued that organizational culture has five main characteristics: (a) organizational culture which is an integral and interconnected unity, (b) organizational culture that is a historical reflection of the organization, (c) Organizational culture relating to things learned by anthropologists, such as rituals, symbols, stories, and personalities, (d) a socially constructed organizational culture, in the sense that an organizational culture is born out of a collective consensus of a group of people establishing an organization and, (e) organizational culture that is difficult to change[21]. In other words, a good organizational culture has a full power not only on individuals and their performance, but also on their work environments.

Culture can be viewed from the level of (1) artifacts and creations such as art, technology or behavior that can be observed; (2) values which are group norms in the form of social consensus or physical environment; and (3) assumptions which are beliefs, perceptions, feelings that are the source of action in the relationship between humans and the environments, human natures, human activities by William(1997:26)[22]. Culture is seen as (1) values / norms referring to forms of statements about what the organization can and can not do, (2) assumptions refer to what is right or wrong by Owens(1991:72)[23]. Organization is defined as a consciously coordinated social unit consisting of two or more persons who function on a relatively continuous basis 
to achieve a common goal or set of goals. This means, the organization consists of people who interact with each other.

Organizational culture is the body of solutions, internal and external problems that are consistently carried out by a group and taught to new members as a perspective, not based on members but adhered to by its members. In general, culture is below the threshold of consciousness because it involves taken-for-granted assumptions about how one sees, thinks, acts and feels and reacts to his environment[23] (Robert Kreitner \& Angelo Kinicki 2001:68). Organizational culture is the values and informal norms that control individuals and groups within organizations in interacting with each other and with organizations outside of the organization[24] (Jennifer M. George, \& Gareth R. Jones 1996:494).

\section{RESEARCH METHOD}

This research is a quantitative research with expost facto research design wher(e the variables studied are not controlled and manipulated by the researcher, but the facts are expressed based on the measurement of symptoms or testing what will happen. The research method used is a survey method and to analyze one variable with other variables, path analysis is used. Analysis of this path requires the existence of a significant linear regression relationship between variables. This research was conducted in Deli Serdang Regency, North Sumatera Province. The time of study is planned from March 2016 until June 2017. The population in this research is 156 principlas of Private Madrasah Ibtidaiyah in Deli Serdang regency. Sampling is done by taking into account the size of the population. The guidelines for determining the sample are Krejcle and Morgan tables in Sugiyono where a sample of 113 people.

\section{FINDING of RESEARCH}

The results of testing requirements analysis indicate that the data research variables have met the criteria for statistical hypotheses and research hypotheses testings. Based on path analysis, path coefficient between $\mathrm{X}$ to $\mathrm{Y}$, it is obtained $\rho_{61}=0,249$ and $t_{\text {observed }}=2,738$. For $N=113$. At a significance level of $5 \%$, it is obtained $t_{\text {table }}=1,658$. The calculation results produce $t_{\text {observeb }}>t_{\text {table }}(2,738>1,658)$. Thus Ho is rejected and Ha accepted, so it can be concluded that organizational culture directly affect the discipline of work. The results of testing the tendency of organizational culture shows the high category of $26.55 \%$, the medium category of $61.95 \%$, the low category of $11.50 \%$ and the less category of $0 \%$. Thus, it can be concluded that the organizational culture in this study tend to be moderate with $61.95 \%$ of respondents fall into the category of medium. If noted, the indicators for the formation of an organizational culture that includes order, hard work, honor and honesty have a moderate effect in influencing the work discipline of the principlas of the madrasahs. Nevertheless, there are still indicators that need attention especially in relation to order and honesty. As is known, the head of the madrasah is the leader of the madrasah. Realizing this, the effort to create order in the presence and execution of the task becomes a necessity.
The test results of the trend of work discipline variables indicate that the high category does not exist, the medium category is $46.90 \%$, the less category is $53.10 \%$ and the low category does not exist. Thus, it can be concluded that the discipline of work in this study is poor that can be seen from the aspect of obedience to the rules, awareness of the implementation of duties and responsibilities to the implementation of tasks. This needs to get the attention of the head of the Ministry of Religious Affairs Deli Serdang. This is a key aspect in relation to improving the work discipline of madrasah heads. The direct influence of organizational culture on work discipline is 0,062 . Thus, organizational culture directly determines madrasah heads work discipline of $6.2 \%$. These findings at least reinforce the view that the work discipline of madrasah heads is influenced by organizational culture. Schein (2004:342) defines organizational culture as a pattern of assumptions learned by organizations in solving problems related to adaptation to the organization's external environment and internal integration between organizational units[25].

Discussion: The findings of this study are in line with findings from Brahmasari's research which conclude that the organizational culture applied by employees has an effect on the increasing attitudes and behaviors of employees' work discipline[26] (Daft 2010:245). Based on the results of his research, the organizational culture consists of values and implementation of the company's missions and visions. The organizational culture employed by employees has an effect on the increase of work discipline and employee performance. The results also support research conducted by Denison and Mishra on organizational culture, work performance and employee quality. The study shows that organizational culture affects the company's performance and employee quality. Organizational culture provides an identity to the individual as part of the organization. Furthermore, Denison (1995:204) said organizational culture will form collective values, mindsets and habits. It establishes behaviors that direct a person able to adapt to work effectively in accordance with company standards and provide a strong collective identity to the members of the organization. The results of this study indicate that organizational culture forming values, patterns of thought and collective habits that direct someone to work according to company standards which includes the attitude and behavior of discipline in work[27].

\section{CONCLUSION}

Based on the results of data analysis, findings and discussion of this study, it can be concluded that the organizational culture positively affects the discipline of the Head of Madrasahs Ibtidaiyah in Deli Serdang. The results of this study indicate that the direct influence of organizational culture on the work discipline of madrasah head is 0.021 . The implications of the findings of this study is that a weak organizational culture and lack of clarity of rules in the organization may result in the madrasah's heads acting irrespectively. The action is an indication that the head of the madrasah has an indiscipline attitude. Conversely, if the madrasah has a good organizational culture, the heads of the madrasah will also build good 
habits. These habits will be embedded in the attitudes of the principlas of the madrasah positively, affecting their attitudes and behaviors and make the principlas of the madrasahs are accustomed to work according to the rules.

\section{REFERENCES}

[1]. B. Kunto Wibisono (Editor), 2013. Indeks Daya Saing Indonesia Naik 12 Peringkat, Antara News.Com Rabu 9 November 2013. (http:// .antaranews.com/berita/406970/indeks-daya-saingindonesia-naik-12-peringat), Diakses pada tanggal 15 September 2014.

[2]. Aldri Frinaldi. 2010. Analisis Hubungan Budaya Organisasi dan Disiplin Kerja Pegawai Negeri Sipil: Studi pada beberapa Pemerintah Daerah di Sumatera Barat. Tesis. Sumatra Barat: Universitas Negri Padang.

[3]. Angelo Kinicki dan Robert Kreitner. 2004. Perilaku Organisasi. Terjemahan. Jakarta: Salemba Empat.

[4]. Anton Sinaga. 2010. Hubungan Antara Disiplin Kerja dan Iklim Organisasi Dengan Kinerja Guru Di SMP Negeri Kelurahan Raya Kabupaten Simalungun. Tesis tidak diterbitkan. Medan: Program Pascasarjana UNIMED Medan.

[5]. Brahmasari, I. A., \& Siregar, P. 2009. Pengaruh budaya organisasi, kepemimpinan situasional dan pola komunikasi terhadap disiplin kerja dan kinerja karyawan pada PT Central Proteinaprima TBK. Jurnal Aplikasi Manajemen.

[6]. Budi Suseno Darmo. 2009. Leader Yang Ship, Panduan Kepemimpinan Praktis dan Efektif. Milestone.

[7]. Daft, R. L. 2010. Management, ${ }^{\text {9th }}$ Edition. Ohio: Cancage Learning.

[8]. Denison, D. R., \& Mishra, A. K. 1995. Toward a theory of organizatioal culture and effectiveness.( International Journal of Organization Science.

[9]. Elbert Carrell and Hatfield. at.al. 1995. Human Recources Management. New Jersey: Prentice Hall.Inc.1995.

[10]. Fred C, Lunenburg and Allan C. Ornstein. 2004. Educational Administration: Concepts and Practices. Belmont: Wadsworth.

[11]. Gary Dessler. 2007. Human Resource Managament. Manajemen Sumber Daya manusia. New York: McGraw Hill, $12^{\text {th }}$ Edition.
[12]. Hofstede, Geert. 1986. Culture's Consequences, International Differences in Work - Related Values. London: Sage Publications.

[13]. Jason A. Colquitt, Jeffery A. Lepine dan Michael J. Wesson. 2009 Organizational Behavior : Improving Performance and Commitment in the Work Place. New Jersey New York : Mc Graw-Hill.

[14]. Jennifer M. George, \& Gareth R. Jones, 1996. Understanding and Managing Organizational Behavior, New York: addison wesley Publishing Co.

[15]. Malayu S.P. Hasibuan. 2005. Manajemen Sumber Daya Manusia. Jakarta: Bumi Aksara.

[16]. Martini M Hadari dan Nawawi, Hadari. 2006. Kepemimpinan Yang Efektif. Yogyakarta: Gadjah Mada University Press.

[17]. Moekijat. 2002. Manajemen Tenaga Kerja Dan Hubungan Kerja. Bandung: Pionir Jaya.

[18]. Rahman (at all). 2006. Peran Strategis Kapala Sekolah dalam Meningkatkan Mutu Pendidikan. Jatinangor: Alqaprint.

[19]. Robert G Owens. 1991. Organizational behavior in Education. (Needham height: Prentice Hall Int., Edition.

[20]. Robert Kreitner \& Angelo Kinicki, 2001. Organizational Behavior, New York: Irwin Mc Graw-Hill, Int. Edition.

[21]. Schein, E. H. 2004. Organizational Culture and Leadership, 3th Edition. San Francisco: John Wiley \& Sons, Inc,

[22]. Soebagia, A. 2000. Manajemen Pendidikan Indonesia. Jakarta: Ardadirya.

[23]. Susilo Martoyo. 2007. Manajemen Sumber Daya Manusia. Cetakan ke1. Yogykarta : BPFE.

[24]. Trilling B. dan Hood, P. 1990. Learning, Technology, and Education Rform in the Knowledge Age or "Were Wirad, Webbed, and Windowed, Now What"? Educational Technology, May-June 1990.

[25]. Veithzal Rifai dan Silviana Murni. 2009. Education Management: Analisis Teori dan Praktik. (Jakarta: Rajawali Pers.

[26]. Wahjosumidjo. 2002. Kepemimpinan Kepala Sekolah. (Jakarta: Raja Grafindo Persada.

[27]. Widyastuti Pratiwiningsih. 2006. Pengaruh Faktor-faktor kepuasan kerja terhadap Disiplin kerja pegawai lembaga pemasyarakatan kelas IIB di Klaten. Jurnal Universitas Muhammadiyah Surakarta.

[28]. William M. Lindsay \& Joseph A. Petrick, 1997. Total Quality and Organizational Development, Florida: St. Lucie Press. 